\title{
HUBUNGAN PSIKOLOGIS IBU BERSALIN DENGAN KELANCARAN PROSES PERSALINAN KALA II DI RB BHAKTI IBU SEMARANG
}

\author{
Shinta Ika Sandhi ${ }^{1}$, Kurniawati Dwi Lestari ${ }^{2}$ \\ 1,2 Universitas Bhakti Kencana \\ Email: shinta86harnuddin82@gmail.com
}

\begin{abstract}
ABSTRAK
Faktor emosi atau psikologis terjadinya partus lama adalah ketakutan dan kecemasan ibu yang tidak teratasi selama melahirkan. 65\% kejadian partus lama disebabkan karena kontraksi uterus yang tidak efisien sebagai respon terhadap kecemasan sehingga menghambat aktifitas uterus. Salah satu penyebab terjadinya partus lama adalah respon stres yang menempati urutan paling atas di antara lainnya. Kondisi ini terjadi karena ibu bersalin akan menghadapi berbagai masalah dalam adaptasinya selama proses persalinan, diantaranya rasa nyeri saat kontraksi, ketakutan akan ketidakmampuan dalam menangani masalah yang akan terjadi, ketegangan dan hiperventilasi. Jenis penelitian survey analitik. Penelitian dilakukan di RB Bhakti Ibu Semarang. Populasi dalam penelitian ini adalah semua ibu bersalin di RB Bhakti Ibu sejumlah 65 responden. Teknik sampling menggunkan sample random sampling dan diperoleh 39 responden. Pengujian hipotesis menggunkaan analisis uji chi square untuk mengetahui hubungan psikologis ibu bersalin dengan kelancaran proses persalinanan kala II. Hasil penelitian menunjukan ada hubungan psikologis ibu bersalin dengan kelancaran proses persalinanan kala II dengan p value 0.000 .
\end{abstract}

Kata kunci : Psikologis, Persalinan Kala II 


\title{
THE PSYCHOLOGICAL RELATIONS WITH THE RELATIONSHIP OF STAGE II LABOR PROCESS AT BHAKTI IBU SEMARANG
}

\begin{abstract}
Emotional or psychological factors for prolonged labor are fear and mothers who are not resolved during childbirth. $65 \%$ of the incidence of prolonged labor is due to inefficient uterine contractions in response to thus inhibiting uterine activity. One of the causes of prolonged labor is the stress response that ranks at the top of the list. This condition occurs because the mother giving birth will face various problems in her adaptation during the labor process, including pain during contractions, fear of inability to troubleshoot problems, busyness and hyperventilation. Type of analytic survey research. The research was conducted at RB Bhakti Ibu Semarang. The population in this study were all women who gave birth at RB Bhakti Ibu totaling 65 respondents. The sampling technique used random sampling and obtained 39 respondents. Hypothesis testing is the chi square test analysis to see the psychological relationship of the mother giving birth with the smooth process of the second stage of labor. The results showed that there was a psychological relationship between the mother giving birth and the smooth process of stage II labor with a p value of 0.000
\end{abstract}

Keywords : Psychological, Childbirth Stage II

\section{PENDAHULUAN}

Setiap hari pada tahun 2017 sekitar 810 ibu di dunia meninggal dunia akibat persalinan. 94 persen dari semua kematian ibu terjadi di negara berpenghasilan rendah dan menengah ke bawah. Menurut laporan World Health Organization (WHO), penyebab langsung kematian ibu terjadi saat dan pasca-melahirkan. 75 persen kasus kematian ibu diakibatkan oleh perdarahan, infeksi, atau tekanan darah tinggi saat kehamilan. Dalam dua dasawarsa terakhir, angka kematian ibu melahirkan di Indonesia masih cukup tinggi, yaitu berkisar 300 per 100.000 kelahiran.

Pada target Milenium Development Goals (MDG's) pada tahun 2015 memiliki target penurunan angka kematian ibu sebesar 102 per 100.000 kelahiran hidup, namun pada pelaksanannya angka kematian ibu di Indonesia masih cenderung tinggi dan belum memenuhi target yang diinginkan. Berdasarkan laporan Survey Demografi Kesehatan 
Indonesia (SDKI) pada tahun 2012 AKI di Indonesia sebanyak 359 per 100.000 kelahiran hidup (Profil Kesehatan Indonesia, 2016)

$$
\text { Berdasarkan kesepakatan }
$$

global dalam Sustainable Development Goals (SDG's) menegaskan bahwa pada tahun 2030 menurunkan Angka Kematian Ibu (AKI) hingga dibawah 70 per 100.000 kelahiran hidup (Dirjen Bina Gizi KIA,2014).

Persalinan merupakan proses alamiah yang dialami seorang wanita. Asalkan kondisi fisik memadai tidak akan banyak mengalami kesulitan, namun tidak setiap wanita akan selalu siap menghadapi parsalinan karena persalinan disertai rasa nyeri dan pengeluaran darah. Ketidaksiapan akan menimbulkan rasa takut dan cemas pada ibu terutama pada wanita yang baru pertama kali melahirkan karena pada umumnya belum memiliki gambaran mengenai kejadian yang akan dialami pada akhir kehamilan terlebih pada persalinan. Kecemasan akan memobilisasi daya pertahanan individu. Cara individu mempertahankan diri terhadap kecemasan dapat dilihat dari gejala-gejala yang menentukan jenis gangguan (Maramis, 2005)

Faktor emosi atau psikologis terjadinya partus lama adalah ketakutan 25 dan kecemasan ibu yang tidak teratasi selama melahirkan. $65 \%$ kejadian partus lama disebabkan karena kontraksi uterus yang tidak efisien sebagai respon terhadap kecemasan sehingga menghambat aktifitas uterus. Salah satu penyebab terjadinya partus lama adalah respon stres yang menempati urutan paling atas di antara lainnya. Kondisi ini terjadi karena ibu bersalin akan menghadapi berbagai masalah dalam adaptasinya selama proses persalinan, diantaranya rasa nyeri saat kontraksi, ketakutan akan ketidakmampuan dalam menangani masalah yang akan terjadi, ketegangan dan hiperventilasi. (Hayati, 2017)

Masalah yang paling umum terjadi pada ibu yang meghadapi proses persalinan tanpa adanya pendampingan yaitu ibu merasa tidak berdaya, rasa panic meningkat dan suami beresiko tidak dapat menempatkan support mereka, meningkatkan adanya tindakan medis. Selain itu ibu merasa takut, cemas dan peningkatan rasa nyeri saat proses persalinan mengakibatkan ibu akan menjadi lelah dan kehilangan kekuatan seingga menggangu jalan persalinan menjadi macet, seperti sungsang, distosia bahu, perpanjangan kala II, kontraksi lemah Oleh karena itu pendampingan suami selama proses 
persalinan sangat dibutuhkan ibu terlebi dahulu pada ibu yang melahirkan anak pertama (Mahyunidar, 2019)

Salah satu penyebab ketidak lancaran proses persalinan adalah fakta psikologi, kecemasan, kelelahan, kehabisan tenaga dan kekhawatiran ibu, seluruhnya menyatu sehingga dapat memperberat nyeri fisik yang sudah ada. Begitu nyeri persepsi semakin intens, kecemasan ibu meningkat semakin berat, sehingga terjadi siklus nyeri stress nyeri dan seterusnya sehingga akhirnya ibu yang bersalin tidak mampu lagi bertahan (Yanti, 2009).

Fenomena yang berkembang selama ini para petugas kesehatan baik dokter, bidan, maupun perawat kebanyakan hanya memperhatikan kondisi fisik dibandingkan dengan pemenuhan kebutuhan kondisi psikis dari ibu dalam menjelang persalinan dan selama persalinan. Kondisi ini dapat memicu terjadinya kecemasan dan rasa takut pada ibu yang sedang melahirkan.
(Dahro, 2012). Tujuan dari penelitian ini adalah ingin mengetahui apakah ada hubungan psikologi ibu bersalin dengan kelancaran proses persalinann kala II di RB Bhakti Ibu Semarang.

\section{METODE PENELITIAN}

Penelitian ini merupakan penelitian analitik kuantitatif dengan rancangan cross sectional. Penelitian ini dimaksudkan untuk menganalisa ada tidaknya hubungan psikologis ibu bersalin dengan kelancaran proses persalinan kala II. Populasi dalam penelitian ini adalah keseluruhan ibu bersalin di rumah bersalin bhakti ibu semarang. Sampel diambil dengan teknik accidental samplingberjumlah 39 ibu bersalin. Alat pengumpulan data dalam penelitian ini adalah lembar observasi, lembar observasi penilaian tingkat kecemasan dan lembar partograf untuk mengamati lama persalinan sampai pada kala II. Rancangan penelitian ini menggunakan cross sectional.

\section{HASIL}

\section{Psikologi Ibu Bersalin}

Distribusi frekuensi responden tentang psikologi ibu disajikan dalam table berikut ini :

Tabel 1. Distribusi Frekuensi Psikologi Ibu

\begin{tabular}{ccc}
\hline Kategori & Frekuensi & Persentase (\%) \\
\hline
\end{tabular}




\begin{tabular}{ccc}
\hline Baik & 13 & 33,3 \\
Cukup & 11 & 28,2 \\
kurang & 15 & 38,5 \\
\hline Jumlah & $\mathbf{3 9}$ & $\mathbf{1 0 0}$ \\
\hline
\end{tabular}

Dari tabel 1 diatas dapat Hasil penelitian yang didapat dari 39 responden di Rumah Bersalin Bhakti Ibu Semarang menunjukkan bahwa responden yang mempunyai psikologi baik dilihat dari tingkat kecemasan dalam menghadapi persalinan kala II sebanyak 13 orang (33,3\%), sedangkan responden yang mempunyai psikologi cukup dilihat dari tingkat kecemasan dalam menghadapi proses persalinan kala II sebanyak 11 orang $(28,2 \%)$, dan responden yanag mempunyai psikologi kurang dilihat dari tingkat kecemasan dalam menghadapi persalinan kala II sebanyak 15 orang $(38,5 \%)$.

\section{Kelancaran Proses Persalinan Kala II}

Distribusi frekuensi responden tentang kelancaran proses persalinan kala II disajikan dalam tabel berikut :

Tabel 2. distribusi Frekuensi Kelancaran Proses Persalinan Kala II

\begin{tabular}{c|cc}
\hline Kategori & Frekuensi & Presentase (\%) \\
\hline Lancar & 19 & 48,7 \\
Tidak lancar & 20 & 51,3 \\
\hline Jumlah & $\mathbf{3 9}$ & $\mathbf{1 0 0}$ \\
\hline
\end{tabular}

Dari tabel 2. diatas dapat dilihat bahwa

Hasil penelitian yang didapat dari 39 rsponden di Rumah Bersalin Bhakti Ibu Semarang menunjukkan bahwa responden yang lancar dalam proses persalinan kala II sebanyak 19 orang $(48,7 \%)$, sedangkan responden yang tidak lancar dalam proses persalinan kala II sebanyak 20 orang $(51,3 \%)$.
Hubungan psikologi Ibu dan Kelancaran Proses Persalinan Kala Il

Analisis bivariate digunakan untuk menguji hipotensi dan untuk mengetahui hubungan antar variable Independent dan variable dependent dengan menguji korelasi Chi-Square. Hasil ui korelasi dapat dilihat pada table dibawah ini : 
Table 3. Hubungan Psikologi Ibu dan Kelancaran Proses Persalinan Kala II

\begin{tabular}{c|cccccc}
\hline \multirow{2}{*}{ Psikologi } & \multicolumn{7}{c}{ Kelancaran } \\
\cline { 2 - 8 } & \multicolumn{2}{|c}{ Lancar } & \multicolumn{2}{c}{ Tidak Lancar } & \multicolumn{2}{c}{ Total } \\
\cline { 2 - 8 } & $\mathbf{N}$ & \% & N & \% & n & \% \\
\hline Baik & 12 & 92,3 & 1 & 7,7 & 13 & 100 \\
Cukup & 5 & 45,5 & 6 & 54,5 & 11 & 100 \\
Kurang & 2 & 13,3 & 13 & 86,7 & 15 & 100 \\
\hline$P=0,00$ & & & & & $X^{2}=17,451$
\end{tabular}

Dari hasil penelitian hubungan antara psikologi ibu dan kelancaran proses persalinan kala II didapatkan bahwa responden yang memiliki psikologi baik yang mengalami kelancaran dalam proses persalinan kala II sebanyak 12 responden (92.3\%), sedangkan responden yang memiliki psikologi baik namun mengalami ketidaklancaran dalam proses persalinan kala II sebanyak 1 responden $(7,7 \%)$. Dari responden yang memiliki psikologi cukup yang mengalami kelancaran proses persalinan kala II sebanyak 5 responden (45,5\%), sedangkan responden yang memiliki psikologi cukup namun mengalami ketidaklancaran proses persalinan kala II sebanyak 6 responden (54,5\%). Dari responden yang mempunyai psikologi kurang, diketahui yang mengalami kelancaran dalam proses persalinan sebanyak 2 responden $(13,3 \%)$ sedangkan responden yang menngalami ketidaklancaran dalam proses persalinan kala II sebanyak 13 responden $(86,7 \%)$.

Dari hasil uji Chi Square terlihat bahwa ada hubungan antara psikologi ibu dan kelancaran dalam persalinan kala II di Rumah Bersalin Bhakti Ibu Semarang. Hal ini dibuktikan karena hasil perhitungan uji korelasi dapat diketahui bahwa nilai $\mathrm{p}=0,000$ yang bearti lebih kecil dari $\grave{\alpha}=0,05 \quad(\mathrm{p}<\dot{\alpha})$, maka Ho ditolak

\section{PEMBAHASAN}

\section{Psikologis Ibu Bersalin}

Berdasarkan data Tabel 1 menunjukkan bahwa sebagian besar responden mempunyai psikologi kurang dilihat dari tingkat kecemasan dalam menghadapi persalinan kala II. Tingkat kecemasan wanita saat bersalin akan meningkat jika ia tidak memahami apa yang terjadi pada dirinya atau yang disampaikan padanya. Dukungan psikologis dari orang-orang terdekat akan membantu memperlancar proses 
persalinan yang sedang berlangsung. Tindakan mengupayakan rasa nyaman dengan menciptakan suasana yang nyaman dalam kamar bersalin, memberi sentuhan, memberi penenangan nyeri non farmakologi, memberi analgesia jika diperlukan dan yang paling penting berada disisi pasien adalah bentukbentuk dukungan psikologi. Dengan kondisi psikologi yang positif proses persalinan akan berjalan dengan mudah. Dukungan psikologi dari orang-orang terdekat akan membantu memperlancar proses persalinan yang sedang berlangsung, karena dengan adanya dukungan psikologi ibu akan merasa tenangdan nyaman dalam menjalani proses persalinan. (Heriani, 2016)

\section{Kelancaran Proses Persalinan Kala II}

Persalinan kala II (pengeluaran) dimulai dari pembukaan lengkap (10 cm) sampai bayi lahir. Proses ini berlangsung 2 jam pada primigravida dan 1 jam pada multigravida. Untuk mencegah partus lama, asuhan persalinan normal mengandalkan penggunaan partograf untuk memantau kondisi ibu dan janin serta kemajuan proses persalinan. Dukungan suami atau kerabat, diharapkan dapat memberikan rasa tenang dan aman selama proses persalinan berlangsung. Pendampingan 29 ini diharapkan dapat mendukung kelancaran proses persalinan, menjalin kebersamaan, berbagi tanggung jawab antara penolong dan keluarga klien. (Sulisdian, 2019)

Salah satu penyebab terjadinya partus lama adalah respon stres yang menempati urutan paling atas di antara lainnya. Kondisi ini terjadi karena ibu bersalin akan menghadapi berbagai masalah dalam adaptasinya selama proses persalinan, diantaranya rasa nyeri saat kontraksi, ketakutan akan ketidakmampuan dalam menangani masalah yang akan terjadi, ketegangan dan hiperventilasi (Brayshaw, 2007)

\section{Hubungan Psikologi Ibu dan}

\section{Kelancaran Proses Persalinan Kala II}

Kelahiran bayi merupakan peristiwa penting bagi kehidupan seorang ibu dan keluarganya. Banyak ibu mengalami psikis (kecemasan, keadaan emosional wanita) dalam menghadapi persalinan, hal ini perlu diperhatikan oleh seseorang yang akan menolong persalinan. Perasaan cemas, khawatir akan mempengaruhi hormone stress yang akan mengakibatkan komplikasi persalinan. Tetapi sampai saat ini hampir tidak ada catatan yang menyebutkan mengenai hormone stress terhadap fungsi uteri, juga tidak ada 
catatan mengenai hubungan antara kecemasan ibu, pengaruh lingkungan, hormone stress dan komplikasi persalinan. Namun demikian seseorang penolong persalinan harus memperhatikan keadaan psikologis ibu yang akan melahirkan karena keadaan psikologis mempunyai pengaruh terhadap persalinan dan kelahiran (Kurniarum, 2016)

Psikologis ibu sangat berpengaruh terhadap factor-faktor yang mempengaruhi persalinan. Keadaan psikologis ibu yang baik akan menghasilkan persalinan yang aman dan lancar. Salah satu factor yang mempengaruhi proses persalinan adalah pendamping persalinan. Ibu bersalin yang didampingi oleh orang terdekat, keluarga, penolong, cenderung mengalami proses persalinan yang lebih lancar disbanding dengan ibu bersalin tampa pendamping. Hal ini menunjukan bahwa dukungan mental berdampak positif bagi keadaan psikis ibu. Sebagian ibu hamil yang memasuki masa persalinan akan merasa cemas apalagi pada ibu primigravida. Oleh karena itu penolong persalinan harus dapat dipercaya dan dapat memberikan bimbingan dan informasi mengenai keadaan ibu saat bersalin. (Widiastini, 2014)
Kecemasan dapat timbul dari reaksi seseorang terhadap nyeri. Hal ini akan meningkatkan aktifitas saraf simpatik dan meningkatkan sekresi katekolamin. Sekresi katekolamin yang berlebihan akan menimbulkan penurunan aliran darah ke plasenta sehinga membatasi suplai oksigen serta penurunan efektifitas dari kontraksi uterus yang dapat memperlambat proses persalinan. Efek dari kecemasan dalam persalinan dapat mengakibatkan kadar katekolamin yang berlebihan menyebabkan turunnya aliran darah ke rahim, turunnya kontraksi rahim, turunnya aliran darah ke plasenta, turunnya oksigen yang tersedia untuk janin serta dapat meningkatkan lamanya Persalinan. Hal ini juga dapat dimungkinkan adanya bayangan mengenai apa yang akan terjadi saat bersalin sehingga ibu merasa ketakutan karena sering mendengar cerita mengerikan tentang pengalaman saat melahirkan dan ini mempengaruhi ibu berfikiran proses persalinan yang menakutkan.

Tingkat kecemasan ibu bersalin akan mempengaruhi lama persalinan, karena perasaan cemas yang dialami oleh ibu selama persalinan dapat merangsang hipotalamus sebagai pusat sistem limbik yang mengatur 
emosional. Hipotalamus akan merangsang kerja sistem saraf simpatis sehingga terjadi vasokontriksi pada organ dan jaringan, termasuk pada uterus, akibatnya asupan darah ke uterus berkurang sehingga oksigen dan nutrisi ke jaringan dan sel otot uterus tidak adekuat. Hal ini akan mengganggu metabolisme sel otot uterus sehingga energi yang dihasilkannya pun berkurang yang pada akhirnya menyebabkan gangguan pada kontraksi uterus. Jika kontraksi uterus terganggu, maka persalinan akan berlangsung lebih lama. ( Hayati, 2017)

Adanya hubungan antara tingkat kecemasan dengan lama persalinan kala II tersebut memiliki kesesuaian dengan teori yang menyebutkan bahwa lama persalinan salah satunya dipengaruhi oleh kondisi psikologis dari ibu yang mengakibatkan ibu mengalami gangguan alam perasaan yang ditandai dengan perasaan ketakutan atau kekhawatiran yang mendalam dan berkelanjutan, mengalami gangguan dalam menilai realitas, kepribadian masih tetap utuh, perilaku dapat terganggu (Sagita, 2018). Hasil penelitian ini memiliki kesamaan dengan hasil penelitian oleh Mahyunidar (2018) dengan judul Hubungan pendamping suami terhadap 31 kelancaran proses persalinan pada ibu primigravida di klinik Murniati Kisaran Tahun 2018 dengan hasil Ada hubungan dukungan psikologi yang diberikan oleh pendamping persalinan terhadap kelancaran proses persalinan.

\section{KESIMPULAN}

Kesimpulan dari penelitian ini adalah :

1. Hasil penelitian menunjukan bahwa jumlah mayoritas responden yaitu sebesar 38,5\% mempunyai psikologi kurang dalam menghadapi persalinan kala II

2. Hasil penelitian menunjukan bahwa jumlah mayoritas responden yaitu sebesar 51,3\% tidak lancar dalam proses persalinann kala II

3. Ada hubungan antara psikologi ibu bersalin dengan kelancaran dalam persalinan kala II.

\section{UCAPAN TERIMA KASIH}

Pada kesempatan ini, peneliti ingin mengucapkan terima kasih kepada Kepala Rumah Bersalin Bhakti Ibu Semarang yang telah membantu terwujudnya penelitian ini. 


\section{DAFTAR PUSTAKA}

Dahro, A. (2012) Psikologi Kebidanan : Analisis Perilaku Wanita untuk Kesehatan. Jakarta. Salemba Medika

Departemen Kesehatan RI (2016). Profil Kesehatan Indonesia 2015. Jakarta. Departemen Kesehatan RI

Direktorat Jenderal Bina Gizi dan Kesehatan Ibu dan Anak (2011). Keputusan Menteri Kesehatan. Jakarta. Kementerian Kesehatan RI.

Maramis, F.W. (2005) Catatan Ilmu Kedokteran Jiwa. Surabaya. Airlangga University Press

Yanti, dkk (2017) Buku Ajar Asuhan Kebidanan Persalinan. Jakarta. Pustaka Rihana

Sulisdian, dkk. (2019) Buku Ajar Asuhan Kebidanan Persalinan dan Bayi Baru Lahir. Surakarta. CV Oase Group

Brayshaw E. (2007) Senam Hamil \& Nifas: Pedoman Praktis Bidan. Jakarta. EGC

Kurniarum. Ari. (2016) Asuhan Kebidanan Persalinan dan Bayi Baru Lahir. Badan Pengembangan dan Pemberdayaan Sumber Daya Manusia. Jakarta Selatan. Kemenkes RI
Widiastini, Luh Putu. (2014) Buku Ajar Asuhan Kebidanan Pada Ibu Bersalin dan Bayi Baru Lahir. Bogor. In Media

Hayati. F (2017). Perbedaan Tingkat Kecemasan Ibu Bersalin di Puskesmas dengan di Bidan Praktik Mandiri dan Hubungannya dengan Lama Persalinan. Jurnal Kesehatan Andalas, Vol.6 (3) : Hal 564-571

Mahyunidar (2019). Hubungan Pendamping Suami Terhadap Kelancaran Proses Persalinan Pada Ibu Primigravida di Klinik Murniati Kisaran Tahun 2018. Excellent Midwifery Journal, Vol 2(2) : Hal 41-46

Heriani (2016). Kecemasan dalam Menjelang Persalinan Ditinjau dari Paritas, Usia dan Tingkat Pendidikan. Jurnal Ilmu Kesehatan Aisyah STIKES Aisyah Pringsewu Lampung, Vol.1(2) : Hal 1-7

Sagita, Desni. Yona (2018). Hubungan Tingkat Kecemasan dengan Lama Persalinana Kala II Pada Ibu Bersalin di RSIA Anugerah Medical Center Kota Metro. Midwifery Journal. Vol. 3(1) : Hal. 16-20 